41 Perani D, Colombo C, Bressi S, Bonfanti A, Grassi F, Scarone S, et al. [18F]FDG PET study in obsessive-compulsive disorder. A clinical/metabolic correlation study after treatment. Br J Psychiatry 1995; 166: 244-50.

42 Machlin SR, Harris GJ, Pearlson GD, Hoehn-Saric R, Jeffery P Camargo EE. Elevated medial-frontal cerebral blood flow in obsessive-compulsive patients: a SPECT study. Am J Psychiatry 1991; 148: 1240-2.

43 Swedo $\mathrm{SE}$, Schapiro MB, Grady $\mathrm{CL}$, Cheslow DL, Leonard $\mathrm{HL}$, Kumar A, et al. Cerebral glucose metabolism in childhood-onset obsessive-compulsive disorder. Arch Gen Psychiatry 1989; 46: 518-23.

44 Phillips ML, Marks IM, Senior C, Lythgoe D, O'Dwyer AM, Meehan O, et al. A differential neural response in obsessive-compulsive disorder patients with washing compared with checking symptoms to disgust. Psychol Med 2000; 30: $1037-50$.
45 Sawle GV, Hymas NF, Lees AJ, Frackowiak RS. Obsessional slowness. Functional studies with positron emission tomography. Brain 1991; 114: 2191-202.

46 Phelps EA, O'Connor KJ, Gatenby JC, Gore JC, Grillon C, Davis M. Activation of the left amygdala to a cognitive representation of fear. Nat Neurosci 2001; 4: 437-41.

47 Becker B, Mihov Y, Scheele D, Kendrick KM, Feinstein JS, Matusch A, et al. Fear processing and social networking in the absence of a functional amygdala. Biol Psychiatry 2012; 72: 70-7.

48 Del-Ben CM, Deakin JF, McKie S, Delvai NA, Williams SR, Elliott R, et al. The effect of citalopram pretreatment on neuronal responses to neuropsychological tasks in normal volunteers: an FMRI study. Neuropsychopharmacology 2005; 30: 1724-34.

49 American Psychiatric Association. Diagnostic and Statistical Manual of Mental Disorders (5th edn) (DSM-5). APA, 2013.

\title{
reflection On Laing's The Divided Self
}

\section{Sandy Robertson}

Re-reading The Divided Self it is hard to recapture the glamour and controversy which surrounded its author in the heyday of antipsychiatry. Fame, drugs and alcohol gave us a different Ronald Laing whose views became increasingly estranged from the clinical mainstream; but his first book is a dense and scholarly work whose complexity derives from his immediate clinical experience, in the analytic setting and in acute wards, combined with an enormous range of reading in existential philosophy and psychoanalysis.

To understand its impact one must recall that the orthodoxy of the age was that psychiatry should be a natural science and therefore ruthlessly objective. Laing reminded us that the subject matter of psychiatry is not only the experience of the patient but that of the psychiatrist; both are embodied subjects, to use Eric Matthews' phrase, and the clinical encounter is a meeting between persons. He criticised the neutral stance of the psychoanalyst and Freudian theory which, like the Medusa's head, turned the terrors of the unconscious to stone. It was this humanising of the clinical situation which won him many adherents among patients and those who identified with them.

Laing's stated aim in the book is to 'make the process of going mad understandable' and his unifying theme is that of ontological insecurity which he believes is central to schizoid and schizophrenic experience. This is a fragile and endangered sense of self which the individual tries to shore up with a variety of defensive stratagems that become increasingly self-defeating until they break down into frank psychosis. Some patients, for instance, only experience themselves as real to the extent that they are experienced by others, but at the same time feel others' experience of them to be intrusive and persecutory. Such complex and paradoxical phenomena are explored with sensitivity and compassion in a series of detailed case histories.

The sceptical psychiatrist, while admiring Laing's analytic and existential insights, may doubt their relevance to those diagnosed with schizophrenia in conventional diagnostic systems. They may also have reservations about the direction of causality: schizophrenia threatens selfhood but this need not mean that ontological insecurity is the cause of schizophrenia. Laing, however, was concerned here with understanding rather than cause; only in later works did he suggest that the cause of schizophrenia lay in family dynamics. Still less is there any suggestion here that the experience of madness is anything other than destructive.

Laing's legacy has had little direct effect on clinical psychiatry. The treatment of psychosis remains largely chemical and social despite the best efforts of cognitive therapists. Its indirect effects, however, have been immense. The anti-psychiatry movement, with which Laing's name is often associated (though he repudiated the label), played a large part in stimulating the thriving disciplines of philosophy and ethics in psychiatry. Patients have found their voice through the 'user' movement and are in dialogue with mental health professionals at all levels. Psychiatrists recognise that content matters, above all to patients, and hopefully are motivated to pursue meaning before concluding that a mental state is truly non-understandable in Jaspers' sense. 